\title{
NEW SPECIES OF CREMASTOSPERMA (ANNONACEAE) FROM COLOMBIA, ECUADOR, AND PANAMA
}

\author{
MICHAEL D. PIRIE \\ Nationaal Herbarium Nederland, Utrecht University branch, Heidelberglaan 2, \\ 3584 CS Utrecht, The Netherlands
}

\begin{abstract}
SUMMARY
In advance of a taxonomic revision of the Neotropical genus Cremastosperma (Annonaceae) nine new species are described here: Cremastosperma antioquense, C. awaense, C. chococola, C. dolichocarpum, C. longipes, C. magdalenae, $C$. napoense, $C$. stenophyllum, and $C$. westrae. A key is presented for the identification of species of Cremastosperma from extra-Amazonian Colombia and Ecuador plus Panama.
\end{abstract}

Key words: Annonaceae, Cremastosperma, Neotropics, taxonomy.

\section{INTRODUCTION}

The genus Cremastosperma R.E. Fr. can most easily be distinguished from other Neotropical Annonaceae with apocarpous, stipitate fruits by its midrib which is raised on the upper side with a mostly conspicuous longitudinal groove. The individual distributions of its species are restricted to four (disjunct) areas: 1) the Chocó/Darién/western Ecuador region (the narrow tropical zone to the west of the Andean mountain chain on the Pacific Ocean side of north-western South America) plus Central America; 2 ) the tropical Andes (including forests on the eastern side of the Andes extending from Colombia through eastern Ecuador and Peru as far south as Bolivia); 3) coastal Venezuela; and 4) French Guiana.

Since the description of the genus by Fries (1930), further work by Fries (1931, 1934, 1937, 1939, 1948, 1950), Maas et al. (1986) and Pirie \& Zapata (2004) brought the total number of species of Cremastosperma to 21. Of these, 16 represent species distributed only in the tropical Andes region, with only one each found in Venezuela and French Guiana, respectively, and three in the Chocó/Darién/western Ecuador region and Central America combined.

Although Chatrou \& Pirie (2005) increased the number of species of Cremastosperma known from Venezuela to two, recent systematic research has revealed a far greater underestimation of species diversity represented in particular by collections from the Chocó/Darién/western Ecuador region. The general increase in numbers of collections of Cremastosperma made since the time of Fries has been restricted in areas of north-western South America. Far fewer were available to the author than for comparable areas on the Amazonian side of the Andean mountain chain. Nevertheless, it is the opinion of the author that the degree of morphological differentiation clear 
from the previously largely undetermined collections that were available demands the recognition of a number of new species.

Fries (1950) described two species from Pacific coastal Colombia: Cremastosperma novogranatense R.E. Fr. and C. pacificum R.E. Fr., and Maas et al. (1986) one species from Panama ( $C$. panamense Maas). In advance of a taxonomic revision of the entire genus, descriptions of a further eight species from extra-Amazonian Colombia and Ecuador plus Panama are presented here. Four are endemic to Colombia, one each to Ecuador and Panama, respectively, and two widespread along the Pacific coast. The species of this region as a whole, demarcated to the east by the Andes, are exclusively endemic. A key is presented for their identification. One new species endemic to Amazonian Ecuador is also described.

\section{KEY TO THE SPECIES OF CREMASTOSPERMA FROM EXTRA-AMAZONIAN COLOMBIA AND ECUADOR PLUS PANAMA}

1a. Leaf lamina 35-60 cm long. Pedicels $>60 \mathrm{~mm}$ long (in flower), $>100 \mathrm{~mm}$ long

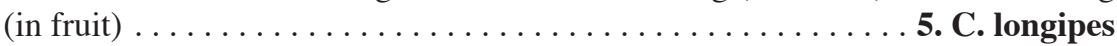

b. Leaf lamina $8-50 \mathrm{~cm}$ long. Pedicels $<60 \mathrm{~mm}$ long (in flower), $<100 \mathrm{~mm}$ long

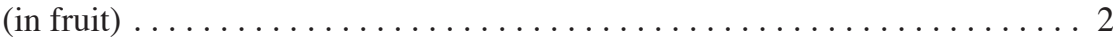

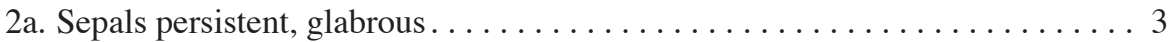

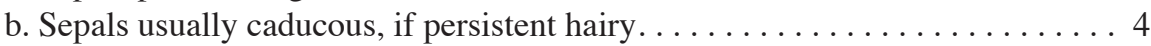

3a. Pedicels $<12 \mathrm{~mm}$ long (in flower). Sepals $(2-) 5-7 \mathrm{~mm}$ long 6. C. magdalenae

b. Pedicels $\geq 12 \mathrm{~mm}$ long (in flower). Sepals $\leq 3 \mathrm{~mm}$ long. . . . . . . . . . . 4

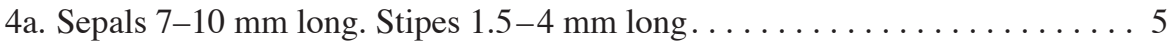

b. Sepals $\leq 4 \mathrm{~mm}$ long. Stipes $>4 \mathrm{~mm}$ long $\ldots \ldots \ldots \ldots \ldots \ldots$

5a. Monocarps sparsely to rather densely covered with hairs c. $0.2 \mathrm{~mm}$ long ......

C. novogranatense

b. Monocarps glabrous or sparsely covered with hairs to $0.1 \mathrm{~mm}$ long $\mathbf{9}$. C. westrae

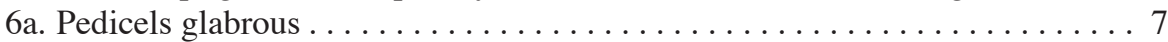

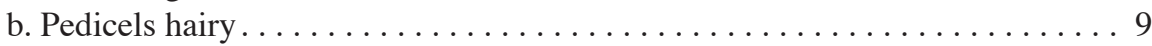

7a. Leaf lamina $\geq 19 \mathrm{~cm}$ long. Monocarps ellipsoid, $\geq 15 \mathrm{~mm}$ long. . C. pacificum

b. Leaf lamina $<22 \mathrm{~cm}$ long. Monocarps ellipsoid or globose, $<15 \mathrm{~mm}$ long . . 8

8a. Inflorescence on leafy or leafless twigs. Monocarps more or less globose, slightly

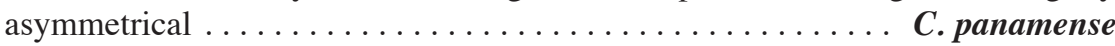

b. Inflorescence on main trunk. Monocarps ellipsoid, strongly asymmetrical . . . .

3. C. chococola

9a. Monocarps $<15 \mathrm{~mm}$ long, strongly asymmetrical, shorter than stipes . . . . . . .

1. C. antioquense

b. Monocarps $>15 \mathrm{~mm}$ long, symmetrical or slightly asymmetrical, equal to or longer than stipes (if no fruits available follow this lead) . . . . . . . . . . 10

10a. Pedicel $<20 \mathrm{~mm}$ long (in fruit or flower) $\ldots \ldots \ldots \ldots \ldots \ldots \ldots \ldots \ldots$

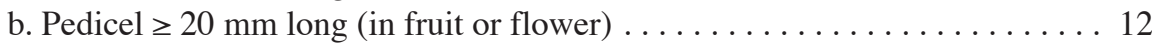

11a. Pedicel $>17 \mathrm{~mm}$ long (in fruit). Sepals and petals glabrous . . . . C. pacificum

b. Pedicel $\leq 17 \mathrm{~mm}$ long (in fruit). Sepals and petals hairy . . . . . 9. C. westrae

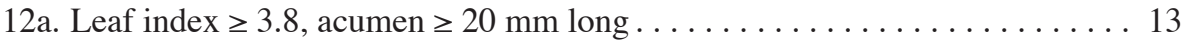

b. Leaf index $\leq 3.6$, acumen $\leq 20 \mathrm{~mm}$ long $\ldots \ldots \ldots \ldots \ldots \ldots \ldots$ 
13a. Pedicels $\leq 28 \mathrm{~mm}$ long (in flower). Petals appear glabrous, but with dense hairs at base and in a line leading to the petal apex ......... 2. C. awaense

b. Pedicel c. $45 \mathrm{~mm}$ long (in flower). Petals evenly covered with hairs . . . . . . . . .

8. C. stenophyllum

14a. Sepals and petals hairy. Monocarps $>20 \mathrm{~mm}$ long . . . . . . . . . 15

b. Sepals and petals glabrous. Monocarps $<20 \mathrm{~mm}$ long . . . . . . . C. pacificum

15a. Petals evenly covered with hairs. Monocarps ellipsoid or narrowly ellipsoid. 16

b. Petals appear glabrous, but with dense hairs at base and in a line leading to the petal apex. Monocarps ellipsoid. . . . . . . . . . . . 2. C. awaense

16a. Leaf axillary buds conspicuously densely hairy. Inflorescences on leafy or leafless

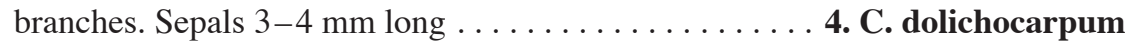

b. Leaf axillary buds inconspicuous. Inflorescence on leafy branches or on the main

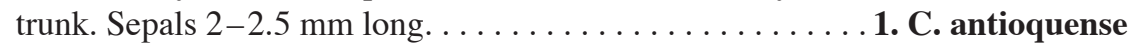

\section{Cremastosperma antioquense Pirie, spec. nov. - Fig. 1; Map 1}

AC. awaense, C. dolichocarpo et C. stenophyllo monocarpiis asymmetricis, a C. chococola pedicellis indumento obtectis (nec glabris) differt. - Typus: Soejarto 3586 (holo COL; iso F, GH, HUA, MO), Colombia, Antioquia, Mun. Anorí, Corregimiento Providencia, Buenos Aires, 4 km from Providencia, 500-700 m, 10 Dec. 1972 (fr).

Tree c. $5 \mathrm{~m}$ tall; young twigs and petioles sparsely covered with appressed brown up to $0.2 \mathrm{~mm}$ long hairs or glabrous. Leaves: petioles $7-10$ by $2-3 \mathrm{~mm}$; lamina narrowly elliptic, $16-27$ by $6-9.5 \mathrm{~cm}$ (index $2.3-2.8$ ), chartaceous, drying to a mosaic of brown and lighter green, glabrous above and below, base obtuse, apex acuminate (acumen $10-15 \mathrm{~mm}$ long), primary vein grooved in the basal half, $1-1.5 \mathrm{~mm}$ wide at widest point, secondary veins $8-11$, intersecondary veins occasional, distance between from

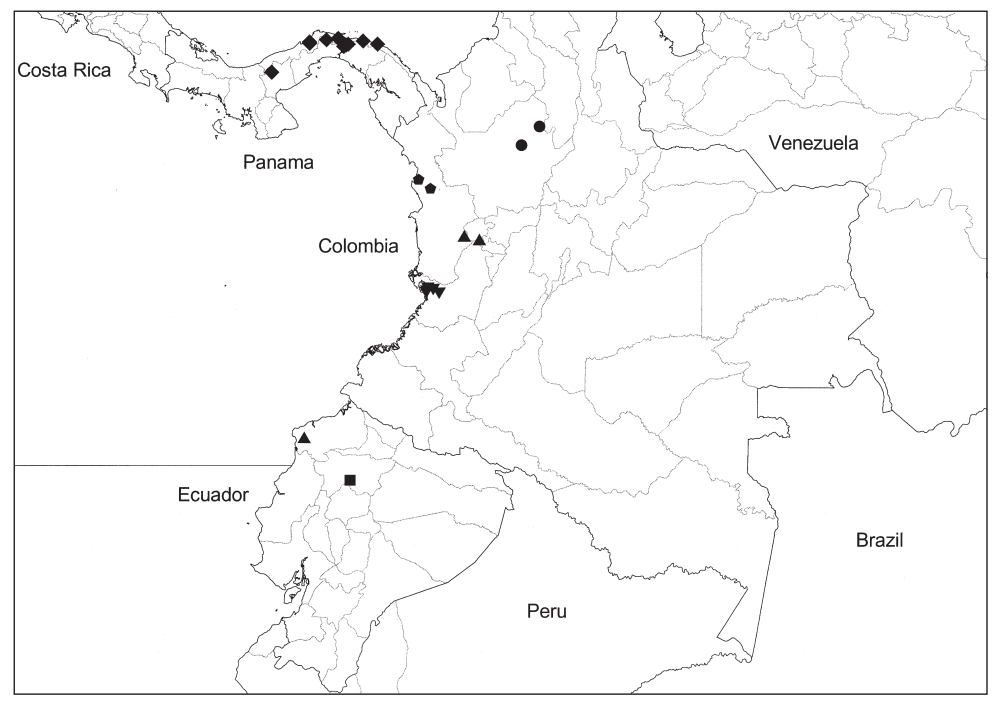

Map 1. Distribution of Cremastosperma antioquense Pirie (•), C. chococola Pirie (•), C. longipes

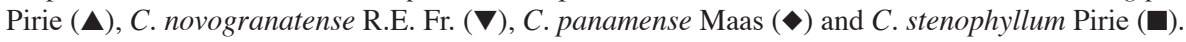




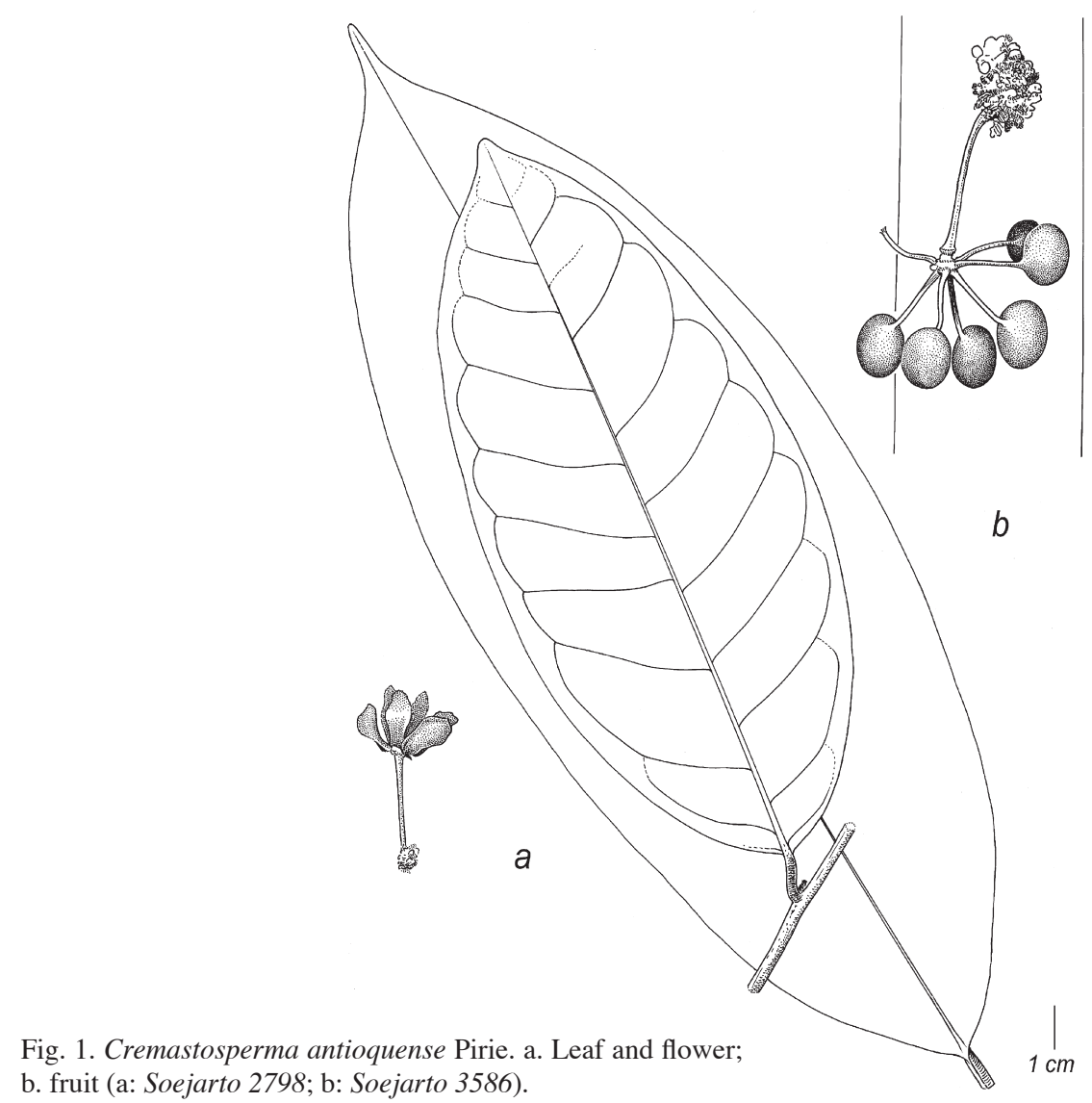

$10 \mathrm{~mm}$ at the base to $50 \mathrm{~mm}$ closer to the apex, angles with primary vein from $50^{\circ}$ at the base to $70^{\circ}$ closer to the apex, forming distinct loops, smallest distance between loops and margin 3-4 mm, tertiary veins more or less percurrent. Inflorescence of single flowers, axillary on leafy twigs or from main trunk, then solitary or clustered in groups of at least two on brachyblasts; peduncles c. 2 by $1.5 \mathrm{~mm}$ (in flower), $2-3$ by $1.5-2 \mathrm{~mm}$ (in fruit); pedicels $20-28$ by c. $1 \mathrm{~mm}$ diam. at the base, $1.5-2 \mathrm{~mm}$ diam. at the apex (in flower), 20-40 by c. $2 \mathrm{~mm}$ diam. at the base, c. $3 \mathrm{~mm}$ diam. at the apex (in fruit), peduncles and pedicels sparsely covered with appressed whitish golden to $0.2 \mathrm{~mm}$ long hairs; 2 lower bracts, deltate, c. $1 \mathrm{~mm}$ long, obtuse, caducous; upper bract attached around halfway along pedicel, deltate, $1 \mathrm{~mm}$ long, obtuse, outer side of upper and lower bracts rather densely to densely covered with appressed whitish golden to $0.2 \mathrm{~mm}$ long hairs; flowers light green, stamens and carpels yellowish or pinkish in vivo, petals dark brown, contrasting to lighter colour of sepals and pedicels in sicco; sepals fused at base, deltate, appressed, $2-2.5$ by $2-2.5 \mathrm{~mm}$, acute, caducous, sparsely to rather densely covered with appressed whitish golden to $0.2 \mathrm{~mm}$ long hairs; outer petals elliptic, c. 12 by $8 \mathrm{~mm}$, inner petals elliptic, $10-12$ by $5-6 \mathrm{~mm}$, outer side of outer and inner petals rather densely covered with appressed whitish golden to $0.2 \mathrm{~mm}$ 
long hairs; receptacle depressed ovoid; androecium 5-7 mm diam., stamens c. $1 \mathrm{~mm}$ long, connective appendage roughly rhombic, $0.5-0.7 \mathrm{~mm}$ wide, glabrous; gynoecium $1-1.5 \mathrm{~mm}$ diam., carpels $30-40$, c. $1.5 \mathrm{~mm}$ long, glabrous. Monocarps c. 10 , ellipsoid, strongly asymmetrical, $13-14$ by c. $11 \mathrm{~mm}$, with an excentral, to $0.2 \mathrm{~mm}$ long, apicule, orange to deep red, maturing to black in vivo, dark reddish brown in sicco; stipes orange to deep red in vivo, c. 20 by $1.5 \mathrm{~mm}$, monocarps and stipes glabrous; fruiting receptacle depressed ovoid, c. $6 \mathrm{~mm}$ diam., glabrous. Seeds ellipsoid, reddish brown with dark pits each surrounded by a raised rim, c. 12 by $9 \mathrm{~mm}$, raphe impressed, encircling seed longitudinally.

Distribution - Colombia (Antioquia).

Habitat \& Ecology — Primary forest at 500-700 m elevation. Flowering: February; fruiting: December.

Note - Cremastosperma antioquense is similar to C. awaense, particularly in the appearance of the flowers. However, the fruits of the two species are more distinct: in contrast to $C$. awaense the monocarps of $C$. antioquense are smaller, shorter than the stipes, strongly asymmetrical and entirely glabrous. In addition, none of the collections of C. awaense display cauliflory, a condition found in both of the two collections of C. antioquense.

Other specimen examined:

Colombia. Antioquia: Municipality of Anorí, Corregimiento Providencia (fl), Soejarto 2798 (COL, GH, HUA).

\section{Cremastosperma awaense Pirie, spec. nov. - Fig. 2; Map 2}

Haec species conspicua praecipue indumento densiusculo in parte basali et in linea mediana a basi usque ad apicem in pagina exteriore petalorum, praeterea monocarpiis et stipitibus ut videtur glabris, sed indumento pilis sparsis brevissimis instructis distincta. C. stenophyllo similis sed pedicellis brevioribus differt. - Typus: Aulestia 842 (holo QCNE; iso U); Ecuador, Carchi: Maldonado, parish of Tobar Donoso, Ethnic Reserve Awá, Sabalera, 900 m, 22 Nov. 1992.

Tree 4-15(-20) $\mathrm{m}$ tall, $8-25 \mathrm{~cm}$ diam.; young twigs and petioles sparsely to rather densely covered with appressed, golden, to $0.3 \mathrm{~mm}$ long hairs. Leaves: petioles 4-11 $(-15)$ by $1.5-3 \mathrm{~mm}$; lamina narrowly elliptic to slightly obovate, $17-33$ by $5.5-13$ $\mathrm{cm}$ (index 2.2-3.6), chartaceous, brown/grey green above, darker below, veins on underside dark brown, glabrous above, veins sparsely to rather densely covered with appressed golden to $0.3 \mathrm{~mm}$ long hairs below, base obtuse to acute, apex acuminate (acumen $10-20 \mathrm{~mm}$ long), primary vein $1-3 \mathrm{~mm}$ wide at widest point, secondary veins $7-11$, intersecondary veins occasional, distance between from $10 \mathrm{~mm}$ at the base to up to $60 \mathrm{~mm}$ closer to the apex, angles with primary vein from $45-50^{\circ}$ at the base to $55-60^{\circ}$ closer to the apex, forming loops in the apical half, smallest distance between loops and margin 1-3 mm, tertiary veins with some reticulation. Inflorescence of single, solitary flowers, axillary on leafy or leafless twigs; peduncles c. 1.5 by $1 \mathrm{~mm}$ (in flower), $1.5-3$ by $1-2 \mathrm{~mm}$ (in fruit); pedicels $27-28$ by c. $1 \mathrm{~mm}$ (in flower), 35-60 by $1-2 \mathrm{~mm}$ (in fruit), peduncles and pedicels rather densely to densely covered with appressed, golden, to $0.3 \mathrm{~mm}$ long hairs; single lower bract, broadly elliptic, $1-2$ by $1-1.5 \mathrm{~mm}$, obtuse, caducous, outer side densely covered with appressed, golden, to $0.3 \mathrm{~mm}$ long hairs; upper bract attached around midway along the pedicel, broadly 
Fig. 2. Cremastosperma awaense Pirie. a. Flower; b. leaf and fruit (a: Aulestia 842; b: Van der Werff 12045).
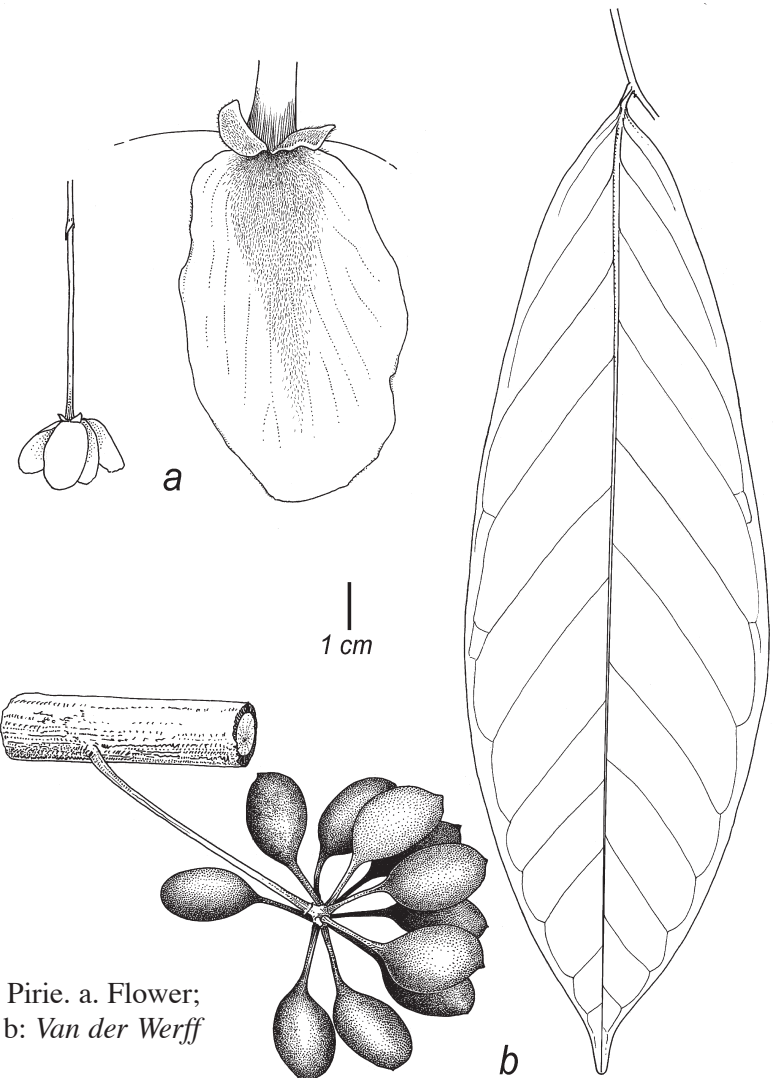

elliptic, $1-2.5$ by $1-2 \mathrm{~mm}$, obtuse, rather densely to densely covered with appressed, golden, to $0.3 \mathrm{~mm}$ long hairs; flower buds depressed ovoid; flowers green or cream in vivo, blackish in sicco; sepals free, deltate, reflexed (appressed in bud), 2-2.5 by 2-2.5 mm, obtuse, caducous, outer side rather densely to densely covered with appressed, golden, to $0.3 \mathrm{~mm}$ long hairs; outer petals elliptic to broadly elliptic, 10-15 by $8-9 \mathrm{~mm}$, inner petals elliptic, $10-15$ by $5-6 \mathrm{~mm}$, appearing glabrous but sparsely to rather densely covered with appressed, golden, to $0.2 \mathrm{~mm}$ long hairs on the outer side, denser at the base and in a band leading from the base to the apex of the petals; stamens 1-1.5 mm long, connective appendage c. $1 \mathrm{~mm}$ wide; gynoecium c. $2 \mathrm{~mm}$ diam., carpels 30-40, 1-2 mm long, sparsely covered with golden, $<0.1 \mathrm{~mm}$ long hairs. Monocarps 10-12(-20), ellipsoid, asymmetrical, $22-28$ by $12-17 \mathrm{~mm}$, brown in sicco, with an excentral apicule or rarely a nipple-like protuberance; stipes 11-24 by $1-1.5 \mathrm{~mm}$; fruiting receptacle depressed ovoid, $3.5-8 \mathrm{~mm}$ diam., monocarps, stipes and receptacle very sparsely to sparsely covered with appressed, white, $<0.1 \mathrm{~mm}$ long hairs. Seeds ellipsoid, asymmetrical, yellow-orange with shallow pits, c. 19 by $11 \mathrm{~mm}$, raphe impressed, encircling seed longitudinally.

Distribution - Pacific coast of Ecuador (Esmeraldas and Carchi) and Colombia (Nariño and Chocó). 


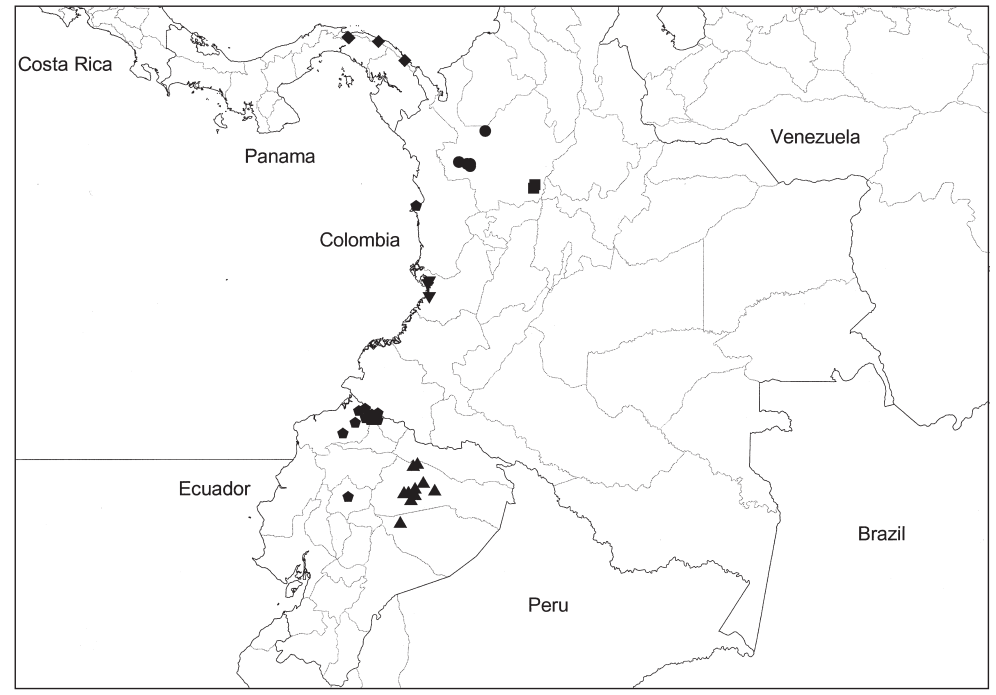

Map 2. Distribution of Cremastosperma awaense Pirie (•), C. dolichocarpum Pirie (-), C. magdalenae Pirie ( $\mathbf{\square})$, C. napoense Pirie $(\boldsymbol{\Delta})$, C. pacificum R.E. Fr. $(\boldsymbol{\nabla})$ and $C$. westrae Pirie $(\bullet)$.

Habitat \& Ecology - Sea level to almost 2000 m elevation in primary humid to premontane tropical forest. Flowering: January, September, November; fruiting: January, February, June to September.

Etymology - Named after the ethnic reserve 'Awá', the type locality in Carchi, Ecuador, in which many of the collections of this species were made.

Note - Cremastosperma awaense can be distinguished by the unique pattern of indument on the outer sides of the petals; denser at base and in a line leading to the petal apex. The sparse indument of very short $(<0.1 \mathrm{~mm})$ hairs on the monocarps and stipes are not visible without magnification, and the fruits appear glabrous. This character is also exhibited by some specimens of $C$. westrae. Cremastosperma awaense can easily be distinguished from both $C$. westrae and the geographically closer $C$. stenophyllum on the basis of the length of the pedicel. That of $C$. westrae is shorter (not exceeding $17 \mathrm{~mm}$ ) and that of C. stenophyllum longer (c. $45 \mathrm{~mm}$ in comparison to $27-28 \mathrm{~mm}$ in flower).

Selection of other specimens (16) examined:

ColOMBIA. Choco: Betancur 6043 (COL, HUA, U, US), Nuquí, corregimiento Termales, between Jobi and Arusi. Forest close to 'las cabañas Pijibá', Pacific coast of Colombia, foothills of la serrania del Baudó, Cabo Corrientes (fl, fr). Nariño: Romero-Castañeda 3369 (VEN) (fr).

ECUADOR. Carchi: Van der Werff 12045 (QCNE, U), Lita - Alto Tambo Road (fr). Esmeraldas: Tirado 591 (MO, US), Eloy Elfaro (fr).

\section{Cremastosperma chococola Pirie, spec. nov. - Fig. 3; Map 1}

C. antioquense, $C$. awaense, $C$. dolichocarpo et $C$. stenophyllo simile sed pedicellis glabris differt. Praeterea monocarpiis asymmetricis et foliis pro rata parvis distinctum. - Typus: Gentry \& Forero 7286 (holo MO; iso COL), Colombia, Chocó, Alto de Buey, 500-1200 m, 8 Jan. 1973 (fr). 
Tree c. $5 \mathrm{~m}$ tall; young twigs and petioles glabrous. Leaves: petioles $5-8$ by $1.5-2 \mathrm{~mm}$; lamina narrowly elliptic, $11-20$ by $4-5.5 \mathrm{~cm}$ (index $3.7-4$ ), chartaceous, dark/olive brown, shiny above, lighter pinkish brown, matt below, glabrous above and below, base acute to cuneate, apex acuminate (acumen 7-10 mm long), primary vein c. $1 \mathrm{~mm}$ wide at widest point, verrucose below, secondary veins $8-10$, no intersecondary veins, distance between from $5 \mathrm{~mm}$ at the base to $29 \mathrm{~mm}$ closer to the apex, angles with primary vein from c. $60^{\circ}$ at the base to $60-70^{\circ}$ closer to the apex, forming distinct loops, smallest distance between loops and margin $2.5-3.5 \mathrm{~mm}$, tertiary veins reticulate. Inflorescence of single flowers, solitary or clustered in groups of at least two, on brachyblasts on the main trunk; peduncles, $2-3$ by $1-1.5 \mathrm{~mm}$ (in fruit); pedicels $38-42$ by $1 \mathrm{~mm}$ diam. at the base, $1 \mathrm{~mm}$ diam. at the apex (in fruit), peduncles and pedicels glabrous; lower bract(s) not observed; upper bract attached within basal half of pedicel, ovate, c. 1 by $0.7 \mathrm{~mm}$, obtuse, glabrous; flowers not observed. Monocarps 10-13, ellipsoid, strongly asymmetrical (stipes inserted within basal half of longest axis), 13-14 by $10-11 \mathrm{~mm}$, with an excentral, to $0.2 \mathrm{~mm}$ long, apicule, green maturing through red to dark blue in vivo, dark brown in sicco, glabrous; stipes $15-18$ by c. $1 \mathrm{~mm}$ increasing to $1.5 \mathrm{~mm}$ diam. when mature, glabrous; fruiting receptacle depressed ovoid, $4-5 \mathrm{~mm}$ diam., glabrous. Seeds ellipsoid, orange-brown, pitted, $9-11$ by $6-8 \mathrm{~mm}$, raphe sunken, encircling seed longitudinally.

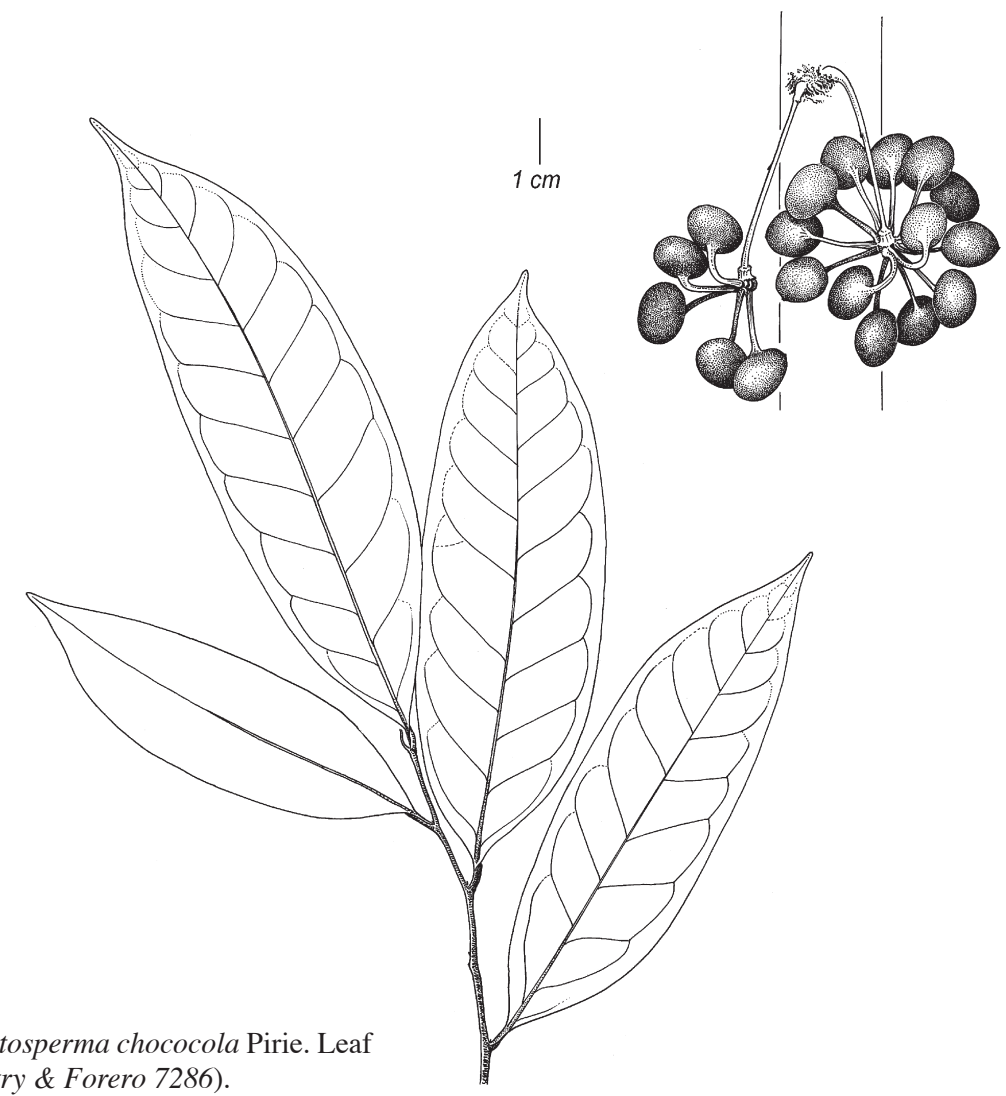

Fig. 3. Cremastosperma chococola
and fruit (Gentry \& Forero 7286$)$. 
Distribution - Pacific coast of Colombia (Chocó).

Habitat \& Ecology - Tropical wet forest. At elevations of 0-1200 m. Fruiting: January, June.

Etymology - Cremastosperma chococola is so named in reference to its being found only in the Colombian department of Chocó.

Note - The strongly asymmetric monocarps of $C$. chococola resemble those of C. antioquense, and collections of both species display cauliflory (though not exclusively so in $C$. antioquense) with inflorescences inserted on similar brachyblasts. However, C. chococola can easily be distinguished by its small, narrowly elliptic leaves with typical pinkish brown colour on the underside, and by the absence of hairs on the pedicels.

Other specimen examined:

Colombia. Chocó: García C. 390 (MO), Utría National Park, west of the bay of Utría, $100 \mathrm{~m}$ along path to Cocalito beach (fr).

\section{Cremastosperma dolichocarpum Pirie, spec. nov. - Fig. 4; Map 2}

Monocarpiis ellipsoideis vel longe ellipsoideis, gemmis axillaribus indumento denso vestitis distinctum. C. antioquense, $C$. stenophyllum et $C$. awaense simile sed petalis longioribus differt. - Typus: Sánchez et al. 415 (holo U; iso COL), Colombia, Antioquia, Frontino, Nutibara, upper watershed of the river Cuevas, 15 July 1986 (fr).

Tree 6-18 m tall, 15-22 cm diam.; young twigs and petioles sparsely covered with white-yellow, appressed, $0.3-0.5 \mathrm{~mm}$ long hairs. Leaves: petioles $3-6$ by $1.5-2 \mathrm{~mm}$, often with warts extending up primary vein; axillary buds densely covered with whiteyellow, appressed, $0.3-0.5 \mathrm{~mm}$ long hairs; lamina elliptic to narrowly so, 14-24.5 by 6-10 cm (index 1.6-3.1), chartaceous or subcoriaceous, mid-dark brown above, lighter below, glabrous above, sparsely covered with white-yellow, appressed, $0.3-0.5 \mathrm{~mm}$ long hairs (particularly on veins) below, base obtuse-acute (narrowly cuneate), apex acuminate (acumen 4-15 mm long), primary vein not conspicuously grooved, 1-2 mm wide at widest point; secondary veins $(5-) 7-9(-11)$, intersecondary veins occasional, distance between from $5 \mathrm{~mm}$ at the base to $30 \mathrm{~mm}$ closer to the apex, angles with primary vein $40-50^{\circ}$ at the base to $50-70^{\circ}$ closer to the apex, not branching, forming distinct loops in the apical $1 / 2-2 / 3 \mathrm{~s}$, smallest distance between loops and margin $1.5-4 \mathrm{~mm}$; tertiary veins percurrent with significant reticulation. Inflorescences of single flowers solitary or clustered in groups of 2 (or more), produced from leafy twigs or leafless branches; peduncles of two internodes, the second 1.2-4 mm long, c. $1 \mathrm{~mm}$ diam. (in flower), c. $2 \mathrm{~mm}$ long, $2 \mathrm{~mm}$ diam. (in fruit); pedicels $28-47 \mathrm{~mm}$ long, c. $1 \mathrm{~mm}$ diam. at the base, $1-1.5 \mathrm{~mm}$ diam. at the apex (in flower), $40-55 \mathrm{~mm}$ long, $1.5-2 \mathrm{~mm}$ diam. at the base, 2-2.5 mm diam. at the apex (in fruit); peduncles and pedicels rather densely covered with white-yellow, appressed, 0.3-0.5 mm long hairs; two lower bracts (one on each internode), the apical one persisting later into flowering, 1-1.5 by 0.7-1 mm, broadly ovate, obtuse, caducous, rather densely covered with white-yellow, appressed, $0.3-0.5 \mathrm{~mm}$ long hairs; upper bract broadly to narrowly ovate, $1-3.5$ by 1-2 mm, obtuse, persistent, densely covered with white-yellow, appressed, 0.3-0.5 $\mathrm{mm}$ long hairs; flower buds depressed ovoid; flowers green maturing to yellow with formaline-like scent in vivo, brown outside and black inside in sicco; sepals free, ovate, 


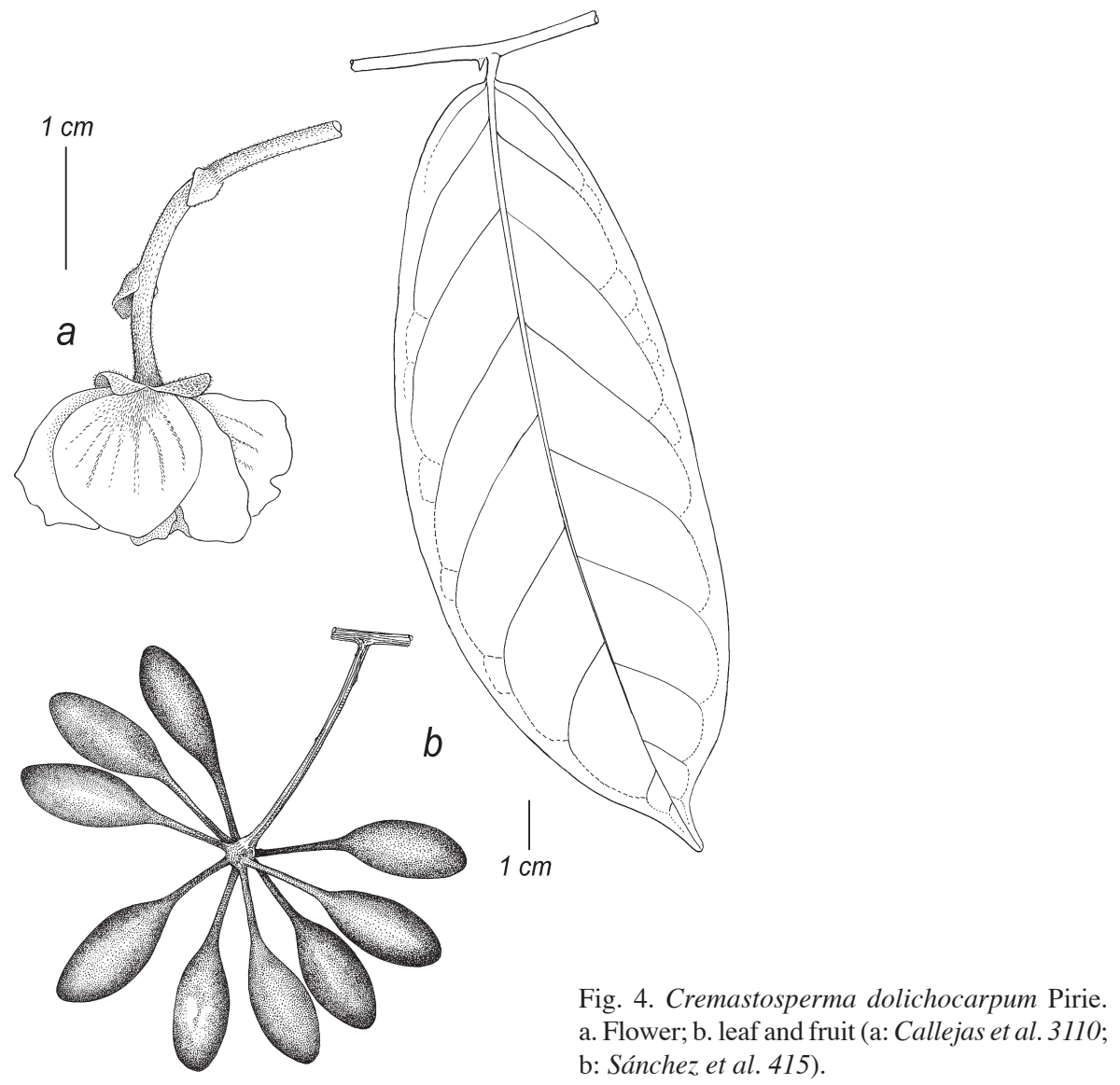

appressed, 3-4 mm long, obtuse, occasionally persistent on less mature fruit, densely covered with white-yellow, appressed, $0.3-0.5 \mathrm{~mm}$ long hairs; outer petals ovate to broadly so, $10-15$ by $9-11 \mathrm{~mm}$, inner petals ovate, $10-16$ by $7-8 \mathrm{~mm}$ densely covered with white-yellow, appressed, $0.3-0.5 \mathrm{~mm}$ long hairs; receptacle ovoid to depressed ovoid; androecium 3-5 mm diam., stamens 1-1.2 mm long, connective appendage c. 1 mm wide, glabrous; gynoecium 1.5-2 mm diam., carpels $0.5-0.6 \mathrm{~mm}$ long, glabrous. Monocarps 10-20 (fully ripe fruit not observed), black in sicco, ellipsoid or narrowly so, 27-28 mm long, 11-12 mm diam., with an excentric apicule (obvious only in immature fruit); stipes $17-19$ by $1.5-2 \mathrm{~mm}$; monocarps and stipes sparsely covered with golden, appressed, $<0.1 \mathrm{~mm}$ long hairs or glabrous; fruiting receptacle broadly ovoid, 4-5 mm diam., often sparsely covered with white-yellow, appressed, 0.3-0.5 $\mathrm{mm}$ long hairs. Seeds ellipsoid to narrowly so, c. $17 \mathrm{~mm}$ long and $7 \mathrm{~mm}$ diam., dark brown and wrinkled, raphe impressed, encircling seed diagonally.

Distribution - Colombia (Antioquia): northern and western foothills of the Cordillera Occidental.

Habitat \& Ecology — At elevations of 1200-1500 m. Flowering: December, May; fruiting: December, May, July. 
Note - Cremastosperma dolichocarpum can be distinguished from other species of Cremastosperma by the unique long-ellipsoid monocarps after which the species is named and identified even when sterile by the conspicuous axillary buds with dense indument.

Selection of (12) other specimens examined:

COLOMBIA. Antioquia: Urrao, 'Las Orquídeas' National Park: Callejas et al. 3110 (HUA, U), 5 Dec. 1986 (fl); Cogollo et al. 6039 (MO), 2 May 1993 (fr, fl). Urrao: Pipoly et al. 16951 (MO), 11 Dec. 1992 (st). Antadó, Paramillo National Park: Gentry et al. 79039 (U), valley of Río San Jorge, 3 March 1993 (st).

\section{Cremastosperma longipes Pirie, spec. nov. - Fig. 5; Map 1}

Foliis magnis et pedicellis longissimis distinctum. - Typus: Forero et al. 6576 (holo COL; iso MO), Colombia, Choco, San José del Palmar, Mouth of river Torito (tributary of River Hábita), west slope, 3 March 1980.

Tree 4.5-15 m tall; young twigs and petioles black, verrucose, sparsely to rather densely covered with white-golden, appressed, c. $0.4 \mathrm{~mm}$ long hairs. Leaves: petioles 10-15 $\mathrm{mm}$ long, 2.5-7 mm diam.; lamina elliptic to narrowly so, 35-60 by $10-25 \mathrm{~cm}$ (leaf index 2.3-3), chartaceous to subcoriaceous, olive/dark brown above, lighter below, glabrous above, sparsely covered with white-golden, appressed, c. $0.4 \mathrm{~mm}$ long hairs on veins below (densely so on developing leaves), base acute, apex acuminate (acumen $10-15 \mathrm{~mm}$ long), primary vein deeply grooved in basal half, 2-6 $\mathrm{mm}$ wide at widest point; secondary veins 10-16, intersecondary veins rare, distance between from 10 $\mathrm{mm}$ at the base to $80 \mathrm{~mm}$ closer to the apex, angles with primary vein $45^{\circ}$ at the base to $60-70^{\circ}$ closer to the apex, not branching, forming distinct loops in the apical half to third of the leaf, smallest distance between loops and margin 3-4 $\mathrm{mm}$; tertiary veins mainly percurrent. Inflorescences of single, pendulous flowers, produced from leafless branches; peduncles 5-8 mm long, c. $1 \mathrm{~mm}$ diam. (in flower), c. $4 \mathrm{~mm}$ long, $2 \mathrm{~mm}$ diam. (in fruit); pedicels 90 (less mature) - $210 \mathrm{~mm}$ long, c. $1 \mathrm{~mm}$ diam. at the base, $1.5 \mathrm{~mm}$ diam. at the apex (in flower), c. $240 \mathrm{~mm}$ long, $2 \mathrm{~mm}$ diam. at the base, $3 \mathrm{~mm}$ diam. at the apex (in fruit); peduncles and pedicels sparsely to rather densely covered with white-golden, appressed, c. $0.4 \mathrm{~mm}$ long hairs; single lower bract, broadly elliptic, 1-2 by c. $1 \mathrm{~mm}$, acute, caducous, densely covered with white-golden, appressed, c. 0.4 $\mathrm{mm}$ long hairs; upper bract attached on lower half of pedicel, elliptic, $1.5-3$ by c. 1 $\mathrm{mm}$, acute, densely covered with white-golden, appressed, c. $0.4 \mathrm{~mm}$ long hairs; closed flower buds not seen; flowers green (immature) in vivo, medium brown in sicco; sepals free, triangular to broadly trullate, 3-4.5 mm long, appressed, acute, caducous, rather densely to densely covered with white-golden, appressed, c. $0.4 \mathrm{~mm}$ long hairs; outer petals elliptic, c. 22 by $12 \mathrm{~mm}$, inner petals narrowly elliptic, c. 22 by $6 \mathrm{~mm}$, sparsely to rather densely covered with white-golden, appressed, c. $0.4 \mathrm{~mm}$ long hairs; stamens, c. $1.2 \mathrm{~mm}$ long, connective appendage rhombic, $1 \mathrm{~mm}$ wide, glabrous. Monocarps c. 20 , black in sicco, ellipsoid, slightly asymmetrical, c. $20 \mathrm{~mm}$ long, $12 \mathrm{~mm}$ diam., without an apicule, glabrous; stipes c. $25 \mathrm{~mm}$ long, $2 \mathrm{~mm}$ diam., glabrous; fruiting receptacle ovoid, $8 \mathrm{~mm}$ diam, sparsely covered with white-golden, appressed, c. 0.4 mm long hairs. Seeds ellipsoid, 18-20 mm long, 8-9 mm diam., orange/brown, with many shallow pits, raphe slightly raised, encircling seed longitudinally. 


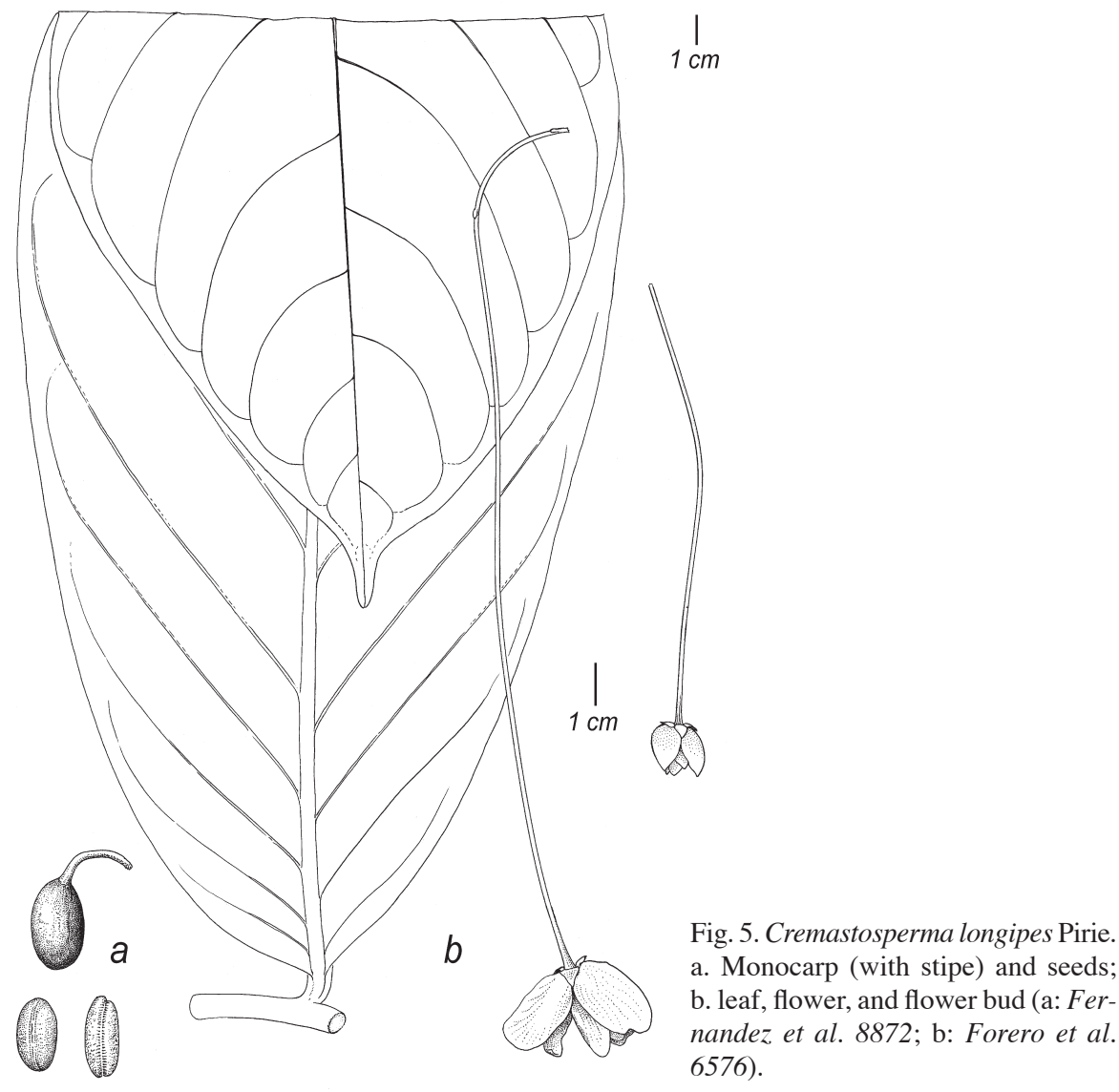

Distribution - Pacific coast of Ecuador (Esmeraldas) and Colombia (Chocó and Riseralda).

Habitat \& Ecology - Humid lowland to pre-montane forest. At elevations of 280-1400 m. Flowering: January, March; fruiting: September.

Notes - Cremastosperma longipes can easily be distinguished from other species of the genus by the exceptional length of the pedicel, after which the species is named. The flowers and fruits of most species of Cremastosperma are borne on pedicels less than $50 \mathrm{~mm}$ long, with rare exceptions such as $C$. pedunculatum (Diels) R.E. Fr. and C. bullatum Pirie never exceeding $150 \mathrm{~mm}$ in length, significantly shorter than those of $C$. longipes. In addition, leaves of $C$. longipes are unusually large, equalling the maximum dimensions observed in C. megalophyllum R.E. Fr., a more densely collected species from Amazonian Colombia, Ecuador, and Peru.

Other specimens examined:

Colombia. Riseralda: Fernández et al. 8872 (COL), Mistrató, road between Geguadas and Puerto de Oro., 13 Sept. 1991 (fr).

ECUADOR. Esmeraldas: Gentry et al. 72995 (MO), Fila de Bilsa, 30 Jan. 1991 (fl). 


\section{Cremastosperma magdalenae Pirie, spec. nov. - Fig. 6; Map 2}

Monocarpiis globosis, sepalis magnis plerumque sub fructu persistentibus, indumento omnino carente disctinctum. C. panamense, $C$. pacifico, $C$. antioquense et $C$. chococola simile sed monocarpiis longitudine stipites excedentibus differt. - Typus: Escobar \& Folsom 3309 (holo NY; iso HUA, U), Colombia, Antioquia, San Luis, Medellín-Bogotá highway 8, $1 \mathrm{~km}$ east of bridge over river Caldera, 13 March 1983.

Tree 3-7 m tall; young twigs and petioles slightly canaliculate and/or verrucose, glabrous. Leaves: petioles 6-14 mm long, 2-3 mm diam.; lamina narrowly elliptic, 20-28 by $7-9 \mathrm{~cm}$ (index 2.5-3.1), chartaceous to subcoriaceous, olive to more lime green or brown above, darker below, glabrous on both sides, base obtuse to acute, apex acuminate (acumen 5-10 mm long), primary vein deeply grooved in basal 1/2-3/4, occasionally verrucose below, c. $2 \mathrm{~mm}$ wide at widest point, glabrous, secondary veins 9-14, often 2 or 3 intersecondary veins, distance between from $4-5 \mathrm{~mm}$ at the base to $20-35 \mathrm{~mm}$ closer to the apex, angles with primary vein from $40-50^{\circ}$ at the base to $70-80^{\circ}$ closer to the apex, occasionally branching, occasionally forming more or less indistinct loops in the apical half, smallest distance between loops and margin $2-4 \mathrm{~mm}$, tertiary veins rather reticulate. Inflorescences of single flowers, solitary or clustered in groups of two, axillary on leafy twigs; peduncles $2-3 \mathrm{~mm}$ long, c. $2 \mathrm{~mm}$ diam. (in fruit); pedicels c. $7 \mathrm{~mm}$ long, $1 \mathrm{~mm}$ diam. at the base, $1.5 \mathrm{~mm}$ diam. at the apex (in flower), 16-20

Fig. 6. Cremastosperma magdalenae Pirie. a. Flower; b. fruiting twig and cross section of seed (a: Hernandez et al. 251; b: Escobar \& Folsom 3309).

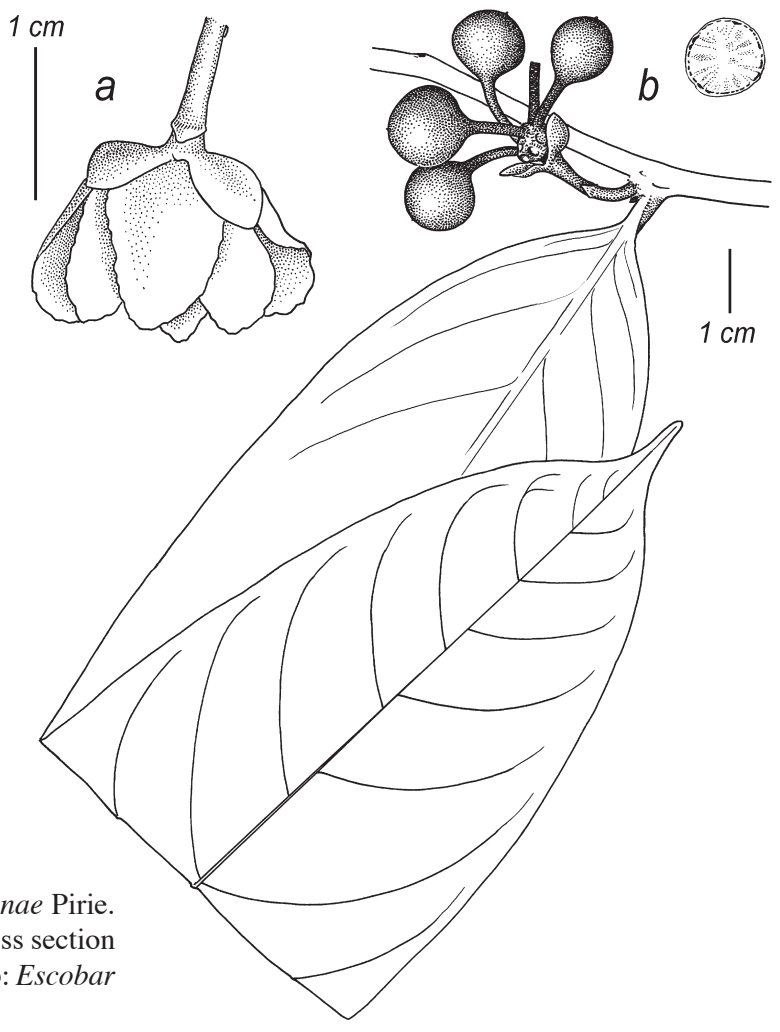


$\mathrm{mm}$ long, 1.5-2 mm diam. at the base, c. $3 \mathrm{~mm}$ diam. at the apex (in fruit), peduncles and pedicels glabrous, two lower bracts, the apical one depressed triangular, c. 1.5 by $2 \mathrm{~mm}$, acute, persistent, glabrous, upper bract attached around midway along pedicel, broadly ovate to deltate, $0.6-2.5$ by $0.8-2.5 \mathrm{~mm}$ wide, acute to obtuse, glabrous; closed flower buds not seen, flowers in vivo immature light green, black in sicco, sepals and petals glabrous; sepals fused for basal $1 \mathrm{~mm}$, broadly to very broadly ovate, appressed, (2-)5-7 by (2-) c. $5 \mathrm{~mm}$, acute, mostly persistent, outer petals elliptic, c. 12 by $7 \mathrm{~mm}$, inner petals narrowly elliptic, c. 12 by $5 \mathrm{~mm}$; androecium $2.5-2.7 \mathrm{~mm}$ diam., stamens c. $0.7 \mathrm{~mm}$ long, connective appendage rhombic, $0.3-0.4 \mathrm{~mm}$ wide. Monocarps 20-30, globose, symmetrical, 12-13 mm long, 12-13 mm diam., green maturing to red in vivo, black in sicco, glabrous, with a slightly excentral, $0.25 \mathrm{~mm}$ long apicule; stipes (immature) 9-10 mm long, 1-1.5 mm diam., glabrous; fruiting receptacle depressed ovoid, 7-9 mm diam. (only immature fruits seen). Seeds globose, shallowly pitted with a papery outer layer, c. 13 by $11 \mathrm{~mm}$, orange-brown, raphe neither raised nor sunken, encircling seed longitudinally.

Distribution - Colombia (Antioquia), west side of the Magdalena valley.

Habitat \& Ecology - Disturbed primary or secondary forest. At elevations of 670-1200 m. Flowering and fruiting: March.

Etymology - Cremastosperma magdalenae is named after the river Magdalena which flows north-east between the central and oriental cordilleras of the northern Andes mountain range in Colombia. It is the only species of Cremastosperma known from this valley.

Note - Cremastosperma magdalenae can be distinguished from other species of the genus by the combination of globose monocarps and large sepals which mostly persist into fruiting (one slightly differing collection, Cárdenas 2899, displays immature fruits with smaller sepals only persistent on one of the two duplicates studied). Also noteworthy are the relatively short pedicels, the short shoot subtending the pedicel comprising of two internodes (indicated by the presence of two lower bracts), and the absence of indument on all parts. The absence of hairs on fruits and flowers reveal the blackish colour typical of specimens of Cremastosperma upon drying. Both C. panamense and C. pacificum (a species found on the Pacific coast of Colombia) also lack indument, but, amongst other differences, the sepals of both species are much smaller and do not persist into fruiting.

Other collections examined:

ColomBia. Antioquia, San Luis: Hernandez et al. 251 (COL, HUA), Medellín-Bogotá highway, between Rivers Samaná and Claro, 19 March 1982 (fl); Juncosa et al. 736 (MO), Medellín-Bogotá highway, $8 \mathrm{~km}$ east of bridge over River Caldera, 13 March 1983 (fr); Cárdenas et al. 2899 (COL, MO), Corregimiento de el Prodigio, Stream el Tigre, 26 June 1990 (fr).

\section{Cremastosperma napoense Pirie, spec. nov. - Fig. 7; Map 2}

Inflorescentia composita atque monocarpiis glabris distinctum. C. caulifloro simile sed petalis indumento minus denso pilis brevioribus differt. - Typus: Alvarado 267 (holo U; iso AAU, MO, QCNE), Ecuador, Napo, Archidonia Cantón, foothills south of Volcano Sumaco, km 50 on Hollín - Loreto road, community Huahua Sumaco, 3 May 1989 (fr).

Tree 5-20 m tall, 10-15 cm diam.; young twigs and petioles rather densely covered with appressed, whitish golden, to $0.2 \mathrm{~mm}$ long hairs. Leaves: petioles $8-12(-18)$ by 


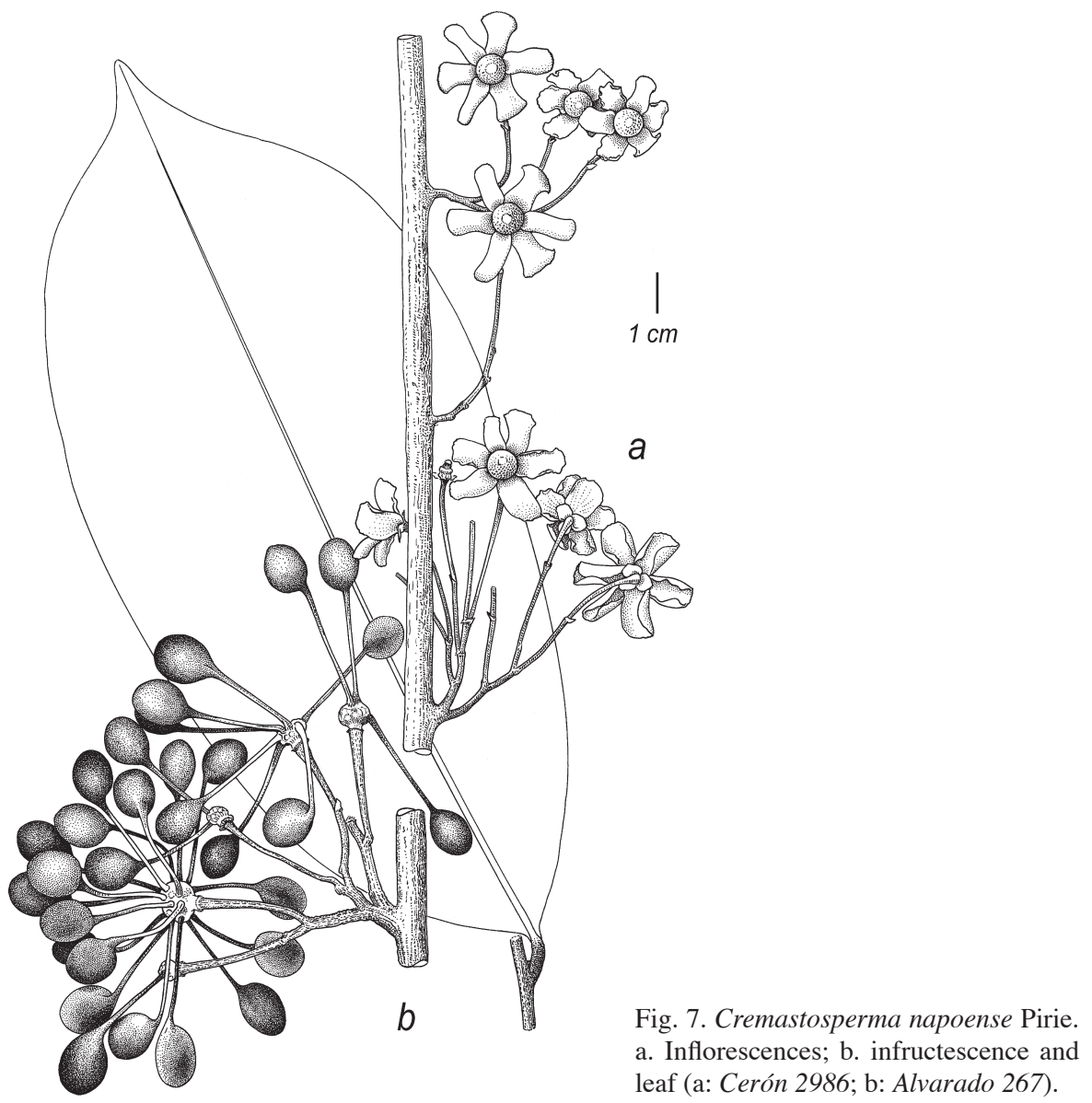

$3-4 \mathrm{~mm}$; lamina narrowly elliptic, $17-42$ by $7-13 \mathrm{~cm}$ (index $1.8-3.9$ ), chartaceous, olive green or brown on both sides, venation darker below, glabrous above, rather densely covered with appressed, whitish golden, to $0.2 \mathrm{~mm}$ long hairs on veins below, base acute, apex acute to acuminate (acumen $5-15 \mathrm{~mm}$ long), primary vein grooved over entire leaf length, verrucose at the base, $3-4 \mathrm{~mm}$ wide at widest point, secondary veins (8-)10-15, occasionally 1 or 2 intersecondary veins, distance between from 4-9 $\mathrm{mm}$ at the base, $20-50(-60) \mathrm{mm}$ in the centre to $10-30 \mathrm{~mm}$ closer to the apex, angles with primary vein from $40-50^{\circ}$ at the base to $70-80^{\circ}$ closer to the apex, occasionally branching, forming more or less distinct loops in the apical half, tertiary veins percurrent. Inflorescence of 1-8 flowers, branching, solitary or clustered in groups of 2, on leafless twigs and branches; peduncles $7-22$ by $1-1.5 \mathrm{~mm}$ (in flower), $10-22$ by $2.5-3$ $\mathrm{mm}$ (in fruit); pedicels $25-38$ by c. $1 \mathrm{~mm}$ diam. at the base, $1.5-2 \mathrm{~mm}$ diam. at the apex (in flower), $25-38$ by $2-3 \mathrm{~mm}$ diam. at the base, $2-4 \mathrm{~mm}$ diam. at the apex (in fruit), peduncles and pedicels rather densely to densely covered with appressed whitish to golden, to $0.2 \mathrm{~mm}$ long hairs; single lower bract, caducous; upper bract attached 
around halfway along the pedicel, broadly to depressed elliptic or broadly to depressed ovate, $1-2$ by $1.5-1.8 \mathrm{~mm}$, obtuse, outer side densely covered with appressed, whitish golden, to $0.2 \mathrm{~mm}$ long hairs; flower buds depressed ovoid, opening early in development; flowers green maturing to greenish yellow or cream in vivo, brown in sicco; sepals fused for first $0.5 \mathrm{~mm}$, deltate, appressed (basal $1 \mathrm{~mm}$ of sepals and petals reflexed), $2.5-3$ by c. $3 \mathrm{~mm}$, acute or obtuse, caducous, inner side glabrous, outer side rather densely to densely covered with appressed, whitish golden, to $0.2 \mathrm{~mm}$ long hairs; outer petals elliptic, $8-15$ by $5-9 \mathrm{~mm}$, inner petals elliptic, $12-14$ by $5-7 \mathrm{~mm}$, inner side of inner and outer petals glabrous, most of outer side of outer petals rather densely to densely covered with appressed, whitish golden, to $0.2 \mathrm{~mm}$ long hairs (towards the margins and apex glabrous), outer side of inner petals largely glabrous but with a narrow, dense, sometimes branching band of appressed, whitish golden, to $0.2 \mathrm{~mm}$ long hairs extending from the base to halfway towards the apex; receptacle depressed ovoid; androecium c. $6 \mathrm{~mm}$ diam., stamens $1-1.5 \mathrm{~mm}$ long, connective appendage roughly hexagonal, $0.5-0.8 \mathrm{~mm}$ wide, glabrous; gynoecium c. $2 \mathrm{~mm}$ diam., carpels up to c. 40 , c. $1.5 \mathrm{~mm}$ long, glabrous or sparsely covered with appressed, whitish golden, to $0.2 \mathrm{~mm}$ long hairs. Monocarps $16-37$, ellipsoid, asymmetrical, $12-20$ by $10-13$ $\mathrm{mm}$, green maturing to dark purple or black in vivo, black in sicco, glabrous; stipes $20-30$ by $2-3 \mathrm{~mm}$, glabrous; fruiting receptacle depressed ovoid, 7-12 $\mathrm{mm}$ diam., glabrous. Seeds ellipsoid, brown, lightly furrowed (not pitted), c. 13 by $9 \mathrm{~mm}$, raphe neither sunken nor raised, encircling seed longitudinally.

Distribution - Ecuador (Napo, one collection Pastaza).

Habitat \& Ecology - Primary pluvial pre-montane forest, often on volcanic soils but also reported growing on limestone. At elevations of 600-1300 m. Flowering: September, November, December, February; fruiting: August to December, March to May.

Note - The characteristic pattern of indument on the inner petals of $C$. napoense appears to be unique for the genus. The species can be further distinguished by the combination of a branching inflorescence and glabrous fruits. The only other species in the genus with such an inflorescence is $C$. cauliflorum R.E. Fr., which differs both in the presence of brown indument on the (characteristic depressed ovoid) monocarps and in the dense hairs on the flowers.

Selection of other specimens (24) examined:

ECUADOR. Napo: Alvarado 427 (U), Archidonia Cantón, Park National Sumaco (fr); Pennington 12266 (K, U), Lumbaqui (fr); Ownbey 2715 (F), north of Archidona on trail between Tena and Baeza (fr). Pastaza: Neill 11048 (U), Pastaza Cantón, 33 km east of Puyo, Colonia Bolívar (fr).

\section{Cremastosperma stenophyllum Pirie, spec. nov. - Fig. 8; Map 1}

Foliis longe ellipticis viridibus in statu sicco distinctum. C. awaensi simile sed pedicellis longioribus, indumento petalorum homogeneo, foliorum acume longiore differt. - Typus: Knapp \& Mallet 6159 (holo QCNE), Ecuador, Pichincha, 'Tinalandia', km 112 on the road to Santo Domingo de los Colorados from Quito, 500-1000 m, 15 Jan. 1984 (fl).

Tree c. $10 \mathrm{~m}$ tall, c. $20 \mathrm{~cm}$ diam.; young twigs and petioles rather densely covered with appressed, golden, to $0.2 \mathrm{~mm}$ long hairs. Leaves: petioles $5-9$ by $2-2.5 \mathrm{~mm}$; lamina narrowly elliptic, $25-30$ by $6.5-8 \mathrm{~cm}$ (index $3.8-4.3$ ), chartaceous, minutely verrucose, 
greyish green above, green below, very sparsely covered with appressed yellowish white, to $0.2 \mathrm{~mm}$ long hairs below and on veins above, base acute, apex acuminate (acumen 20-25 mm long), primary vein 1-1.5 mm wide at widest point, verrucose, secondary veins $8-10$, intersecondary veins occasional, distance between from $5 \mathrm{~mm}$ at the base to $50 \mathrm{~mm}$ closer to the apex, angles with primary vein from $45-55^{\circ}$ at the base to $70-80^{\circ}$ closer to the apex, not branching, not forming loops, tertiary veins with some reticulation. Inflorescence of single flowers ( 1 flower observed) on brachyblasts on thicker twigs or branches; peduncle c. 1.5 by c. $1 \mathrm{~mm}$ (in flower); pedicels c. 45 by c. $1 \mathrm{~mm}$ (in flower), peduncles and pedicels and outer side of bracts (densely), sepals (densely), and petals (sparsely to rather densely) covered with appressed, yellowish white, to $0.2 \mathrm{~mm}$ long hairs; 2 lower bracts, deltate, c. $1 \mathrm{~mm}$ long, obtuse; upper bract attached on basal half of pedicel, ovate, c. 1.5 by $0.8 \mathrm{~mm}$, acute; flowers green, maturing to yellow in vivo, light brown with dark brown patches at the base of the petals in sicco; sepals deltate, $2 \mathrm{~mm}$ long, obtuse; outer petals elliptic, c. 18 by $8 \mathrm{~mm}$, inner petals elliptic, c. $18 \mathrm{~mm}$ long (diam. unknown). Fruit not seen.

Distribution - Ecuador (Pichincha and Bolívar). At elevations of 500-1200 m.

Habitat \& Ecology - Secondary vegetation with primary elements. Flowering: January.

Fig. 8. Cremastosperma stenophyllum Pirie. Flower and leaf (Knapp 6159).

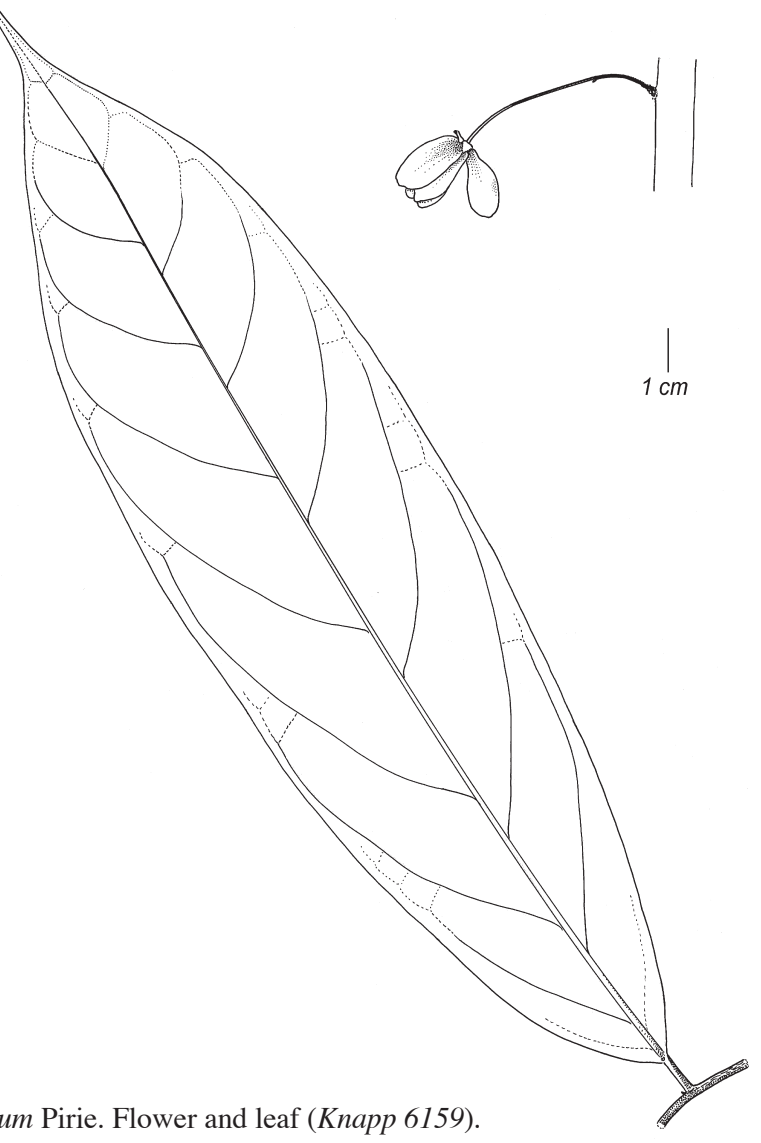


Note - Only two collections of C. stenophyllum, one of which sterile, have been observed by the author. However, these are consistently distinct from all other species of the genus. Cremastosperma stenophyllum can be distinguished even when sterile by the conspicuously green-drying, narrowly elliptic long acuminate leaves. The flower somewhat resembles those of $C$. awaense, but both the pedicel and leaf acumen are longer and $C$. stenophyllum also lacks the distinctive pattern of indument on the petals of $C$. awaense: the hairs are instead evenly distributed on the outer surfaces.

Other specimen examined:

ECUADOR. Bolívar: Acosta Solís 6429 (F), Valle de Limón.

\section{Cremastosperma westrae Pirie, spec. nov. - Fig. 9; Map 2}

A C. novogranatense stipitibus longioribus, sepalis minoribus, petalis indumento minus denso pilis brevioribus differt. A C. pacifico floribus et fructibus indumento obtectis (nec glabris) differt. - Typus: Liesner 682 (holo MO), Panama, Panama, road from El Llano to Carti-Tupile, 12 miles above Pan-American Highway, 200-500 m, 13 March 1973 (fl, fr).

Tree or shrub 4-8 m tall; young twigs and petioles sparsely to densely covered with appressed, brown, c. $0.1 \mathrm{~mm}$ long hairs. Leaves: petioles $6-20$ by $3-6 \mathrm{~mm}$; lamina narrowly elliptic to slightly obovate or narrowly so, (15-)30-50 by (8-) $12-20 \mathrm{~cm}$ (index 1.6-3), chartaceous to coriaceous, dark to olive green or brown above, lighter below, glabrous above, sparsely covered with appressed, whitish, c. $0.1 \mathrm{~mm}$ long hairs on veins below, base acute to rounded, apex acuminate (acumen 10-20 mm long), primary vein $2-5 \mathrm{~mm}$ wide at widest point, secondary veins $8-12$, no intersecondary veins, distance between from $5-10 \mathrm{~mm}$ at the base to $40-60 \mathrm{~mm}$ closer to the apex, angles with primary vein from $50-80^{\circ}$ at the base to $45-60^{\circ}$ closer to the apex, not branching, forming more or less distinct loops in apical half, smallest distance between loops and margin 2-5 mm, tertiary veins mostly percurrent. Inflorescence of single, solitary flowers, on leafy or leafless twigs; peduncles, $2-3$ by $2-3 \mathrm{~mm}$ (in fruit); pedicels $6-17$ by $2-3 \mathrm{~mm}$ (in fruit), peduncles and pedicels rather densely to densely covered with erect, whitish, $0.1 \mathrm{~mm}$ long hairs; single lower bract, caducous; upper bract attached in the basal half of the pedicel, depressed ovate, c. 1.5 by $2 \mathrm{~mm}$, rounded, outer side densely covered with appressed, brown, $0.2 \mathrm{~mm}$ long hairs; flower buds depressed ovoid, flowers yellow in vivo, black with yellow indument in sicco; sepals free or fused for basal $0.5 \mathrm{~mm}$, deltate, appressed, $2.5-3$ by $2.5-3 \mathrm{~mm}$, rounded, often persistent, densely covered (outside, sparsely inside) with appressed, brown, $0.2 \mathrm{~mm}$ long hairs; outer petals elliptic to slightly ovate, c. 9 by $5 \mathrm{~mm}$, rather densely to densely covered (outside, sparsely inside) with appressed, brown, c. $0.2 \mathrm{~mm}$ long hairs, inner petals elliptic, c. 8 by $4 \mathrm{~mm}$, rather densely to densely (towards the apex outside, sparsely inside and at base) covered with appressed, brown, c. $0.2 \mathrm{~mm}$ long hairs; androecium c. $6 \mathrm{~mm}$ diam., stamens c. $1.3 \mathrm{~mm}$ long, connective appendage c. $0.7 \mathrm{~mm}$ wide, glabrous; gynoecium c. $1 \mathrm{~mm}$ diam., carpels sparsely covered with erect, brown, $<0.1 \mathrm{~mm}$ long hairs. Monocarps $6-10$, ellipsoid, slightly asymmetrical, $18-22$ by $10-12 \mathrm{~mm}$, green, maturing to yellow, orange, red or black in vivo, reddish to blackish brown in sicco, with a small excentric apicule, monocarps and stipes sparsely to rather densely covered 


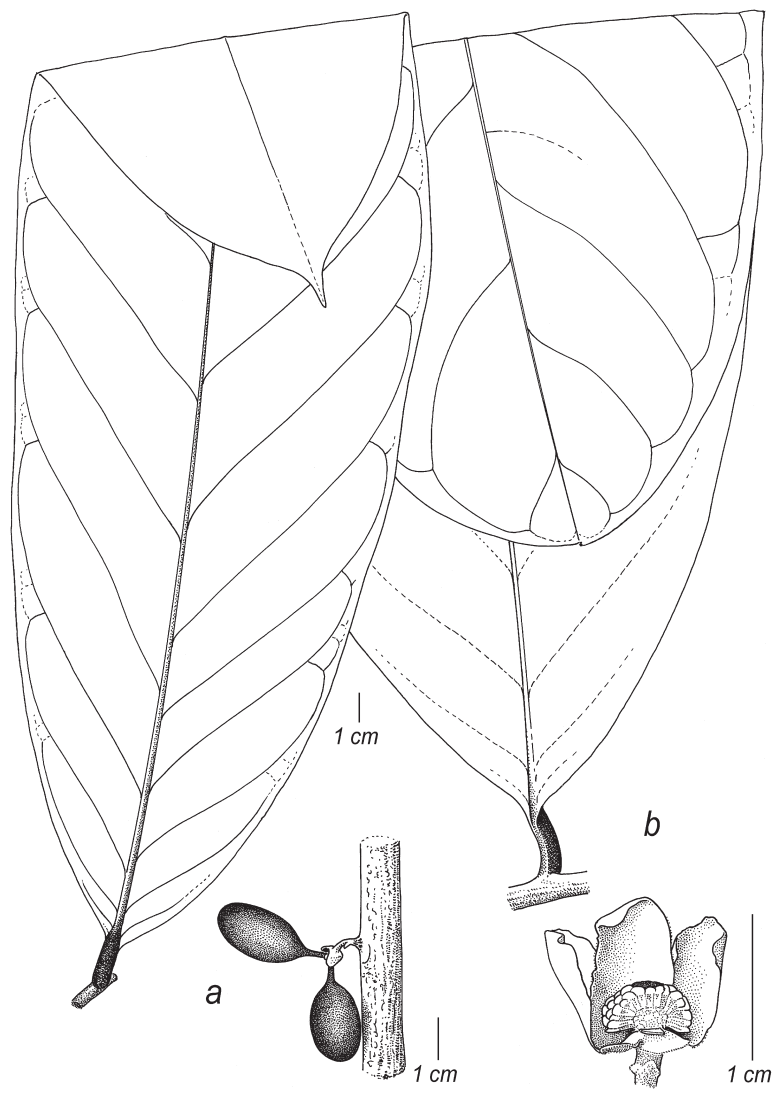

Fig. 9. Cremastosperma westrae Pirie. a. Fruit and leaf (acuminate apex); b. flower and leaf (apex broken off) (a: De Nevers 4475; b: Liesner 682).

with erect, whitish, $<0.1 \mathrm{~mm}$ long hairs or glabrous; stipes $4-14$ by $1-2 \mathrm{~mm}$; fruiting receptacle depressed ovoid, 3-6 mm diam., densely covered with erect, whitish, $<0.1$ $\mathrm{mm}$ long hairs. Seeds ellipsoid, reddish brown, surface wrinkled and slightly pitted, c. 16 by $10 \mathrm{~mm}$, raphe slightly sunken, encircling seed longitudinally.

Distribution - Panama (Darién, San Blas and Panamá).

Habitat \& Ecology - Primary seasonal evergreen forest on red clay. At elevations of 50-600 m. Flowering: March; fruiting: January, March, July, November, December.

Etymology - Cremastosperma westrae is named after the Dutch botanist Lubbert Y.Th. Westra, whose lifelong dedication to plant systematics includes, in the last two decades, a great contribution to the taxonomy of Neotropical Annonaceae. His encyclopaedic knowledge remains an invaluable and much appreciated resource to colleagues at the Utrecht branch of the National Herbarium of the Netherlands and further afield.

Notes - Cremastosperma westrae is most similar to $C$. novogranatense: it differs in having longer stipes, smaller sepals, and less dense, shorter hairs on the petals. The shape of the fruits of $C$. pacificum bear a resemblance to those of $C$. westrae. 
A clear distinction can be made due to the presence of indument on flowers and fruits in $C$. westrae: those of $C$. pacificum are glabrous.

Cremastosperma westrae is reported to contain cardiac glycosides (W. Wint, on Sudgen 613).

Other specimens examined:

Panama. Darien: Oliver 3681 (MO), Camp Summit, adjacent to Darién-San Blas border along Sea Level Canal Route 17, (fr). San Blas, Comarca de San Blas: Herrera 1122 (U), Cordillera de San Blas; McDonagh 291 (MO), trail along Continental Divide (fr); De Nevers 4475 (U), Continental Divide trail to W from El Llano-Carti Road at km 12.2, for 5 km (fr); Sugden 613 (MO), Aila Tiwar (Río Acla) (fr).

\section{ACKNOWLEDGEMENTS}

The herbarium curators of AAU, COL, F, GH, HUA, K, MO, NY, QCNE, U, US, and VEN are acknowledged for the loan of collections. Maps were produced using ESRI data made available by the New York Botanical Garden's 'Digital Basemap of the Americas'. Hendrik Rypkema's art work, Paul Maas' criticism of the manuscript, and Lubbert Westra's translation of the diagnoses are gratefully acknowledged.

\section{REFERENCES}

Chatrou, L.W. \& M.D. Pirie. 2005. Three new rarely collected or endangered species of Annonaceae from Venezuela. Blumea 50: 33-40.

Fries, R.E. 1930. Revision der Arten einiger Anonaceen-Gattungen I. Acta Horti Berg. 10, 1: $1-128$.

Fries, R.E. 1931. Revision der Arten einiger Anonaceen-Gattungen II. Acta Horti Berg. 10, 2: 129-341.

Fries, R.E. 1934. Revision der Arten einiger Anonaceen-Gattungen III. Acta Horti Berg. 12, 1: $1-220$.

Fries, R.E. 1937. Revision der Arten einiger Annonaceen-Gattungen IV. Acta Horti Berg. 12, 2 : 221-288.

Fries, R.E. 1939. Revision der Arten einiger Annonaceen-Gattungen V. Acta Horti Berg. 12, 3: 289-577.

Fries, R.E. 1948. Annonaceae from Tropical America. Kongl. Svenska Vetenskapsakad. Handl. 24: $3-5$.

Fries, R.E. 1950. Contributions to the knowledge of the Annonaceae in northern South America. Ark. Bot. 1: 329-331.

Maas, P.J.M., E.C.H. van Heusden, J. Koek-Noorman, A.K. van Setten \& L.Y.Th. Westra. 1986. Studies in Annonaceae. VII: New species from the tropics and miscellaneous notes. Proc. Kon. Nederl. Akad. Wetensch., Ser. C 89: 249-278.

Pirie, M.D. \& M. Zapata C. 2004. Three new endemic species of Cremastosperma (Annonaceae) from the Río Marañon basin, Amazonas, Perú. Arnaldoa 11, 2: 7-20. 